\title{
ULTRAMORPHOLOGY OF THE METAPLEURAL GLAND IN THREE SPECIES OF ATTA (HYMENOPTERA, FORMICIDAE)
}

\author{
Luciana G. de Gusmão ${ }^{1}$ \\ Flávio Henrique Caetano ${ }^{2}$ \\ Octavio Nakano ${ }^{1}$
}

\begin{abstract}
Differences among the metapleural glands of four female castes of Atta bisphaerica Forel, 1908, A. capiguara Gonçalves, 1944 and $A$. sexdens rubropilosa Forel, 1908 were examined by scanning electron microscope. There were no differences in gland size between the same castes of these species, although the opening gland in $A$. sexdens rubropilosa had been twice as large as A. bisphaerica. The relative size and functional significance of the metapleural gland among different castes is discussed and similarities between these and the other Formicidae till now studied is presented.
\end{abstract}

KEYWORDS. Atta, metapleural gland, morphology.

\section{INTRODUCTION}

Metapleural glands (also called metasternal or metathoracic glands) occur only in ants. Tulloch et al. (1962) and Hölldobler \& ENGEL-SiEGEL (1984) have described them for several species and shown that they exhibit a common basic pattern. They are paired and located on the two posterolateral corners of the thorax. Each gland consists of a group of glandular cells that secrete into a collecting sac which in turn empties into a reservoir immediately below the integument. The reservoir opens onto the surface of the integument through a small opening and in some species it is large enough to form a visible external swelling or bulla. This gland has been shown to produce antibiotic secretions in several species of ants, inhibiting the growth of bacteria (MASCHWITZ et al., 1970; IzZuKa et al., 1979 e Veal et al., 1992), fungi and fungal spores (MASChwitz et al., 1970; BeatTie et al., 1985; Beattie et al., 1986; SchildKneCht \& Koob, 1971) and even pollen grains (BEATTIE et al., 1985). The size and function of this gland is thus potentially important in mediating the outcome of interactions between the ants and microbial and fungal pathogens.

In this study we examined differences among the metapleural glands of four female castes of three leaf cutter ants, Atta bisphaerica Forel, 1908, A. capiguara Gonçalves, 1944 and A. sexdens rubropilosa Forel, 1908, to explore the relationship between gland size and its efficience. The unsuccess of rearing of A. bisphaerica and A. capiguara in laboratory can possibly be related with metapleural gland size and the efficience of its secretion against fungi and bacteria.

\section{MATERIAL AND METHODS}

All castes (typified by differences in length) of Atta bisphaerica and A. capiguara as well as minor workers and queens of $A$. sexdens rubropilosa were collected in the field, four months after the period of nuptial flights,

\footnotetext{
1. Depto de Entomologia, Fitopatologia e Zoologia Agrícola, Escola Superior de Agricultura “Luiz de Queiroz”, Universidade de São Paulo, C.P. 9, 13418-900, Piracicaba, SP, Brasil.

2. Depto de Biologia, Instituto de Biociências, Universidade Estadual Paulista, C.P. 199, 13506-900, Rio Claro, SP, Brasil.
} 
near Piracicaba, São Paulo (22 $42^{\prime}$ S, $47^{\circ} 38^{\prime}$ W, 580 m). Foragers and soldiers of A. sexdens rubropilosa were collected from the laboratory colony (Departamento de Entomologia, Escola Superior de Agricultura "Luiz de Queiroz", Universidade de São Paulo).

Specimens of minor worker $(3 \mathrm{~mm})$, forager $(10 \mathrm{~mm})$, soldier $(15 \mathrm{~mm})$ and queen $(25 \mathrm{~mm})$ from $A$. bisphaerica, A. capiguara and A. sexdens rubropilosa were examined by scanning electron microscopy (SEM). The thoraces were dissected and metapleural glands were removed. These material were fixed in $4 \%$ paraformaldehyde and $2.1 \%$ glutaraldehyde in $0.08 \mathrm{M}$ sodium phosphate buffer $\mathrm{pH} 7.3$ for 2 hours. Subsequently, they were dehydrated through an ethanol series $(70,80,90,95,100 \%)$, ethanol plus acetone (1:1), acetone (100\%) and were critical point dried (Balzers CPD/030). They were mounted on aluminium stubs, sputter coated with gold-paladium (Balzers SCD/ 050) and examined with a Jeol JMS P15. The photographs of metathoracic region and metapleural gland of different castes with the same scale were compared among them.

\section{RESULTS AND DISCUSSION}

All species showed a semicircular slit opening very close to the articulation of the hindleg coxae in all castes. The opening of the gland was surrouded by a furrow (figs.1,2) which suggested in combination with movements of the coxae, to allow the trickle of secretion protecting intersegmental areas which are more susceptible to entomopathogenous penetration and making it accessible for spreading over the body.

Cuticular hairs associated with the gland opening were totally absent (figs. 1-4), whereas in Camponotus gigas (Latreille, 1802), Cataulacus intrudens (F. Smith, 1876), Crematogaster sp., Podomyrma pulchra Forel, 1901 (Hölldobler \& ENGEL-SiEgel, 1984), Crematogaster striatula Emery, 1892 (FANFANI \& DAZZINI, 1991), Diacamma rugosum (Le Guillou, 1842) and D. vagans (F. Smith, 1860) (SCHOETERs \& Billen, 1992) they are obviously present outside.

Although in A. sexdens rubropilosa the opening gland of queen has been twice as big as $A$. bisphaerica (figs.3,4), there were no differences in opening of metapleural gland among other castes studied. Similar difference was not observed in queens of Myrmecia gulosa (Fabricius, 1775) and M. urens Lowne, 1865 (Angus et al., 1993).

The morphology of the metapleural gland in both species was very much alike. The collecting chamber recovered by secretory cell clusters and the visible reservoir were found (fig. 5), the glandular cells showed a rounded form (fig. 6), whereas in $D$. rugosum and $D$. vagans the secretory cells near the centre of the metapleural gland typically had a rounded form, while the peripheral cells appear as elongated columnar or cylindrically shaped (SCHOETERS \& BiLLen, 1992).

Minor workers presented fewer secretory cells than other castes, but they showed the highest relative development when referring to size of thorax. The same was reported by Schoeters \& Billen (1993). If the tasks of the different castes are considered, this means that the minor workers are active on the fungus garden have larger metapleural glands relative to their body size than the large ants that function mostly outside the nest as foragers or defenders (Вот \& Bооммма, 1996).

CAEtano (1984) reported that the minor workers of A. bisphaerica, A. capiguara, A. laevigata and $A$. sexdens rubropilosa have the biggest crop proportionally to the size of the digestive tube from the studied castes. Considering that all of the castes have the same feeding, the differences among them are related with their tasks.

In a recently set colony there is only the queen growing a little fungus garden and the first workers what emerge are minor once (HölLDOBLER \& Wilson, 1990), all this individuals will be the main responsibles for the establishment and development of the 


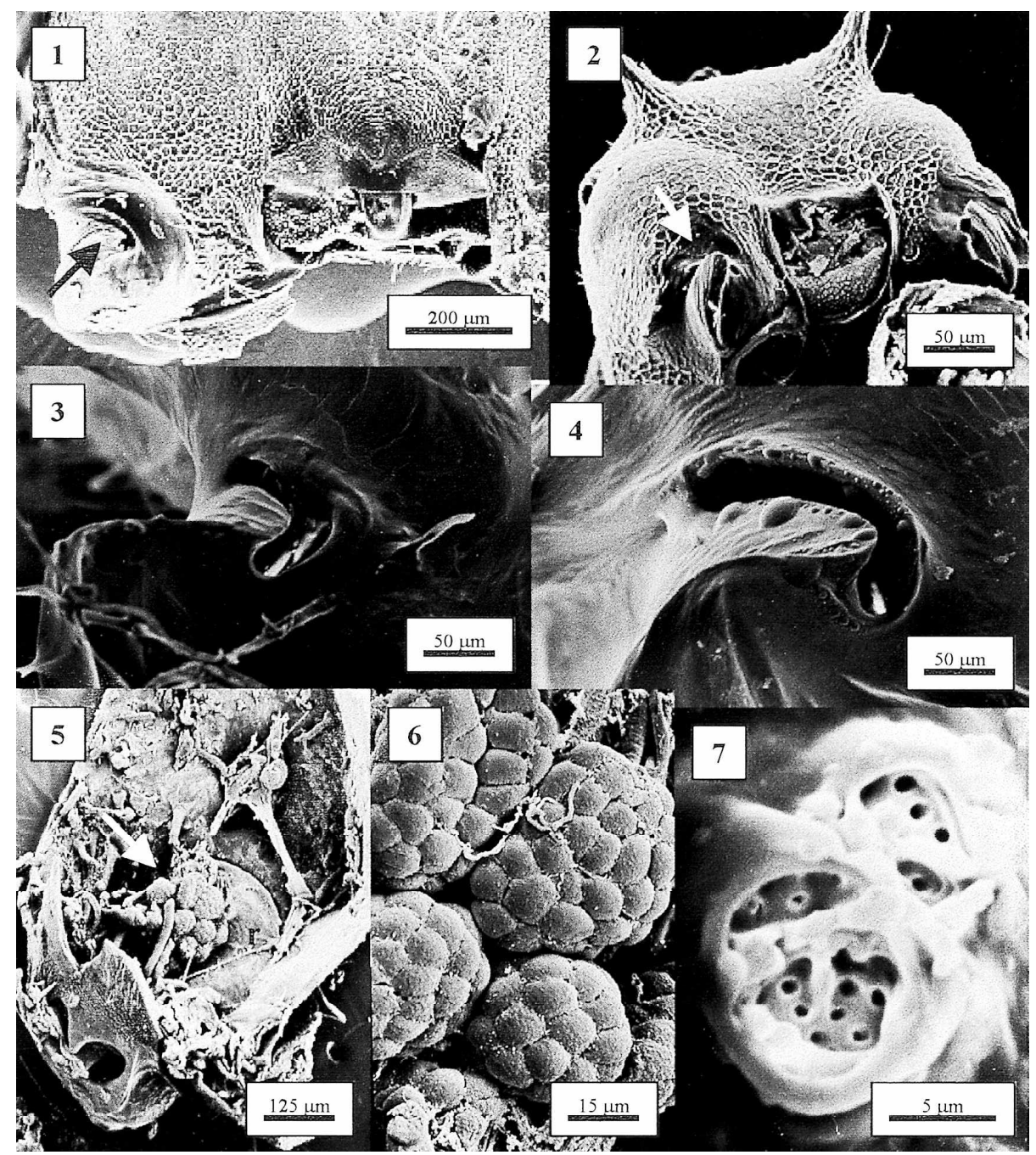

Figs. 1-7. Opening of metapleural gland (arrow) of Atta spp.: 1, soldier (Atta capiguara); 2, minor worker (A. sexdens rubropilosa); 3, queen ( $A$. bisphaerica); 4, queen (A. sexdens rubropilosa). A. sexdens rubropilosa: 5 , internal view of metathoracic region showing a metapleural gland (white arrow) and a reservoir; 6 , secretory cell clusters; 7, A. bisphaerica, sieve plate with many openings.

new colony, by using metapleural gland secretion, to inhibit the growth of soil microorganisms and to stimulate development of symbion fungus. This fact may explains the greater size of metapleural gland of the queen in comparing with other castes observed by us. Angus et al. (1993) observed that queens of Myrmecia gulosa and M. urens, showed approximately twice as many gland cells as worker, similar differences were observed in other genera (HöLLDOBLER \& ENGEL-SIEGEL,1984), supporting the hypothesis 
that ant organs are maximally developed in the castes where they are most crucial (BoT \& Boomsma, 1996).

The internal surface of the collecting chamber of queens of $A$. sexdens rubropilosa and $A$. bisphaerica was very irregular and showed sieve plates which receive the duct cells (fig.7) similarly as described by Tulloch et al. (1962). This characteristic may occur in other castes because their metapleral glands showed similarities among them.

Data of metapleural gland in Atta cephalotes (L., 1758), A. sexdens (L.) (Hölldobler \& Engel-Siegel, 1984), minor workers of $A$. sexdens sexdens (L., 1758), soldiers of $A$. bisphaerica, queens of $A$. laevigata (F. Smith, 1858), workers and minor workers of $A$. sexdens rubropilosa (SCHOETERS \& BiLlen, 1993), together with present results showed that there are no morphological differences among Atta spp. metapleural gland till now studied. However, we observed that the size of metapleural gland is different among the castes, enlarging from minor worker to queen.

Acknowledgments. To CNPq for the scholarship and financial support.

\section{REFERENCES}

Angus, C.J.; Jones, M.K. \& BeAtTie, A.J. 1993. A possible explanation for size differences in the metapleural glands of ants (Hymenoptera: Formicidae). J. Aust. ent. Soc., Canberra, 32 (1):73-77.

BeATTIE, A.J.; TuRnBULl, C. et al. 1985. The vunerability of pollen and fungal spores to ant secretions: evidence and some evolutionary implications. Am. J. Bot., Austin, 72(4):606-614.

. 1986. Antibiotic production: a possible function for the metapleural glands of ants (Hymenoptera: Formicidae). Ann. ent. Soc. Am., Lanham, 79:448-450.

Bот, A.N.M. \& Boомsмa, J.J. 1996. Variable metapleural gland size-allometries in Acromyrmex leafcutter ants (Hymenoptera: Formicidae). J. Kans. ent. Soc., Lawrence, 69(4) (suppl.):375-383.

CAETANo, F.H. 1984. Morfologia comparada do trato digestivo de formigas da subfamília Myrmicinae (Hymenoptera: Formicidae). Papéis Avuls Zool., São Paulo, São Paulo, 35(23):257-305.

Fanfani, A. \& DazzinI, M.V. 1991. Le glandole metatoraciche di Crematogaster striatula (Hymenoptera, Formicidae, Myrmicinae). Fragm. ent., Roma, 23(1):191-200.

Hölldobler, B. \& Engel-Siegel, H. 1984. On the metapleural gland of ants. Psyche, Cambridge, 91(3/4): 201-224. Hölldobler, B. \& Wilson, E. 1990. The ants. Cambridge, Mass., The Belknap of Harvard University. 732p.

IzUKA, T.; IfADARE, T. \& ORITO, K. 1979. Antibacterial activity of myrmicacin a compound in the secretion of South American leaf-cutting ant Atta sexdens and related compounds on pathogenic bacteria in silkworm larvae, Streptococcus faecalis AD-4. J. Fac. Agri., Hokkaido, 59:262-266.

Maschwitz, U.; Коов, K. \& S Child KNecht, H. 1970. Ein Beitrag zur Funktion der Metapleuraldrüse der Ameisen. J. Insect Physiol., New York, 16:387-404.

SCHILKNECHT, H. \& KоOв, K. 1971. Plant bioregulators in the metathoracic glands of Myrmicine ants. Angew. Chem., Berlin, 10:124-125.

SCHOEters, E. \& Billen, J. 1992. Morphological and ultrastructural study of metapleural gland in Diacamma (Hymenoptera, Formicidae). In: European Congress of Social Insects, 1丷, Leuven, 1991. Proceedings... Leuven, Leuven University. p.239-247.

- 1993. Anatomy and fine structure of the metapleural gland in Atta (Hymenoptera, Formicidae). Belgian J. Zool., Brussels, 123(1):67-75.

Tulloch, G.S.; Shapiro, J.E. \& Hershenov, B. 1962. The ultrastructure of the metasternal glands of ants. Bull. Brooklyn ent. Soc., Southern Pines, 57:91-101.

Veal, D.A.; Trimble, J.E. \& BeatTie, A.J. 1992. Antimicrobial properties of secretions from the metapleural gland of Myrmecia gulosa (Australian bull ant). J. appl. Bact., Rearing, 72:188-194.

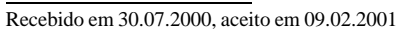

